\title{
PROBLEMS OF REAL ESTATE MANAGEMENT WITH RESPECT TO CLAIMS FOR RESTITUTION OF EXPROPRIATED PROPERTIES
}

\author{
Anna Trembecka, PhD \\ AGH University of Science and Technology \\ Faculty of Mining Surveying and Environmental Engineering \\ e-mail:trembec@agh.edu.pl
}

Anita Kwartnik-Pruc, assoc. prof., PhD

AGH University of Science and Technology

Faculty of Mining Surveying and Environmental Engineering

e-mail:akwart@agh.edu.pl

\begin{abstract}
This research paper discusses the issue of the influence of claims for restitution of expropriated real properties on the process of managing public property. Owners of expropriated properties in Poland are protected in the real estate management process. It consists in the legislator imposing an obligation on the public legal entity to notify the entitled persons about the possibility to seek restitution of their properties if the intended purpose of expropriation has not been implemented and if the property is planned to be used for other purposes by the executive body.

The thesis of this research paper is the statement that current legal regulations, in particular as regards the obligation to notify former owners, bring about problems in the process of the managing real estate owned by the State Treasury and local government units.

The objective of this research paper is to identify problems in the process of public property management with respect to the rights of former owners to seek restitution of expropriated properties.

Amendments to the regulations on real estate restitution were proposed in order to streamline the processes of rational real estate management, while respecting the principle of protecting property rights.
\end{abstract}

Key words: property restitution, real estate management.

JEL Classification: R52.

Citation: Trembecka A., Kwartnik-Pruc A., 2018, Problems of Real Estate Management with Respect to Claims for Restitution of Expropriated Properties, Real Estate Management and Valuation, vol. 26, no. 3, pp. 105-112.

DOI: $10.2478 /$ remav-2018-0029

\section{Introduction}

Real estate expropriation is a tool used in many countries. Protection of the rights of the owner of expropriated real estate has its legitimacy either in the constitution of a given country - as is the case, for example, in Germany (Article 14 of GRUNDGESETZ of 1949), France (CONSTITUTION of 1958, Article 17 of Declaration of Human Rights of 26 August 1789), Spain (Article 33 of CONSTITUCión of 1978), or Poland (Article 21 of CONSTITUTION of 1997), or in a normative act of statutory rank, as it was resolved in countries with a federal structure, such as Canada or the USA (ŹRÓBEK ŹRÓBEK 2007; DU PLESSIS 2011). The rules governing expropriations and relevant compensations based on legal regulations, in 
Poland and in other countries, are presented in the publications (HARRINGTON 2002; ŹRÓBEK 2006; ŹRÓBEK WALACIK, 2008; ŹRÓBEK ŹRÓBEK 2008; ŚMIAŁOWSKA-UBERMAN KWARTNIK-PRUC 2009; SUMRADA FERLAN LISEC 2013; BRIGHTMAN 2016) as well as studies of international organizations (FAO 2008; FIG 2010). The research paper (WALACIK 2012) presents the guidelines for property expropriation in Norway, and the study (WALACIK RICHARD ADAMUSCIN 2013) contains a comparative analysis of the procedure of property valuation used in the expropriation procedure in Poland, Slovakia and the United States.

As a rule, expropriation is to serve a public purpose which meets the needs of the general public. Unfortunately, these declarations are not always reflected in the laws of individual countries. The literature demonstrates examples of studies on restitution of real estate expropriated in postcommunist countries before 1990 (REIMANN 1997; LuX MiKeSZOVÁ 2012; PADURE TUTUIANU 2015; TRIANTIS 2018). At present, it is also the case that not every former owner has the right to seek restitution for their properties if the public purpose which it had been expropriated for has not been implemented. In Canada and Germany, there are regulations of different rank which stipulate that, if the expropriating authority does not use the property for a given purpose within a specified period of time, the property may be returned to the former owner. For example, at the national level, such a solution is provided for in Canada by the Act respecting the expropriation of land (ACT 1985), and in Germany by Baugesetzbuch (BAUGESETZBUCH 1960). In France, on the other hand, the Code de l'expropriation pour cause d'utilité publique (CODE 2015) provides for retrocession for a period of 30 years for properties which were expropriated and not developed within five years. In Italy, the Testo unico delle disposizioni legislative e regolamentari in materia di espropriazione per pubblica utilità (DECRETO 2001) allows for restitution of a property if the purpose of expropriation has not been implemented within ten years. Former owners may also attempt to seek restitution for the unused part of the property. However, there are countries such as Sweden, the United States and Australia, where this is impossible (DU PLESSIS 2011).

In Poland, the owners of expropriated real estate are covered by special protection in the process of public property management. Under Art. $136 \mathrm{sec} .2$ of the Act (USTAWA 1997), the legislator imposes an obligation on the public legal entity to notify the entitled persons about the possibility to seek restitution of their properties if the intended purpose of expropriation has not been implemented and if this property is planned to be used for other purposes by the executive body. The application for restitution must be submitted by authorized persons within three months from the date of receipt of the notice of the possibility of restitution. Failure to do so results in the expiration of the right to seek restitution of the property or part thereof.

The objective of this research paper is to identify problems in the process of public property management with respect to the rights of former owners to seek restitution of expropriated properties.

The thesis of this research paper is the statement that current legal regulations regarding restitution of expropriated properties, in particular as regards the obligation to notify former owners, bring about problems in the process of management of the real estate owned by the State Treasury and local government units. The research method applied is a case study.

The issue of real estate restitution is the subject of the publication (TREMBECKA 2014), which analyzes the problems arising in the course of relevant proceedings and emphasizes the importance of surveying and legal documentation in this respect. The publication (TREMBECKA 2015 a) discusses issues related to real estate management conducted by the commune's executive body in a given area, being the result of pending proceedings for the restitution of expropriated properties and the annulment of expropriation. Based on the conducted research, the scope and types of claims of former owners in relation to the investment areas located in Krakow were presented.

This research paper is aimed at identifying problems in real estate management related to the obligation to notify persons entitled to restitution of their property, and those associated with assessing whether the purpose of expropriation has been implemented.

The research methodology involved the analysis of legal conditions for claims for restitution of expropriated properties with view to public property management. The analyzed issue refers to the whole territory of Poland, but for a more detailed presentation of the problem, the real estate located in the selected city (Krakow) and earmarked for disposal by tender in the years 2015-2017, was examined. The study covered as follows:

- surveying and legal documentation including archival files of the former Austrian cadastre,

- methods of acquiring real estate to be included in public resources, 
- extent of expropriated properties,

- assessment of the expropriation purpose and its implementation,

- possible claims of former owners,

- obligation to notify about the possibility of restitution,

This documentation is available in the Department of Treasury of the Municipal Office of the City of Krakow.

\section{Premises for restitution of expropriated properties}

The premises for restitution of expropriated properties include the following cases:

- the former owner or their heirs have filed an application for restitution of the expropriated property,

- the application for restitution regards only the expropriated property (or part thereof), i.e. the real estate to which the State Treasury or a specific local government unit have acquired the right in rem by means of expropriation, as well as the property acquired under the provisions of laws listed exhaustively in Art. 216 of (UsTAWA 1997),

- the public-law entity has ownership right to the expropriated property which provides legal right to restitution of expropriated rights in rem (JAWORSKI, PRUSACZYK, TUŁODZIECKI, WOLANIN, 2015),

- the property which was expropriated for the purpose set out in the decision on expropriation under Art. 137 (USTAWA 1997), is redundant. Article 137 provides a legal definition of redundancy for property earmarked for expropriation.

Under Art. 4 clause 4 of the Act (UstaWA 1997), the former owner should be understood as a person who has been deprived of the ownership right to a property as a result of its expropriation or acquisition for the benefit of the State Treasury or the local government unit, based on other legal titles. In practice, however, it happens (TREMBECKA, $2015 \mathrm{~b}$ ) that, on the day of expropriation, the ownership right to the property was held by a person other than the one in the expropriation decision, e.g. as a result of a court decision issued after the date of expropriation, adjudicating of acquisitive prescription prior to the expropriation, or when the deed on land ownership was issued based on the Act (USTAWA 1971), which is declaratory and confirms the acquisition of real property on November 4, 1971.

In Poland, only the owners or their heirs may claim for restitution of the property within 3 months as of the date of receiving notification of such a possibility. However, in Germany, other property holders may also claim the restitution of expropriated rights. The application for restitution of the property must be submitted within 2 years (ŹRÓBEK 2006).

The redundancy conditions are stipulated in Art. 137 of (UsTAWA 1997), under which the property is considered redundant with respect to the purpose specified in the expropriation decision in the case of:

- expiration of the term of 7 years from the date of the decision on expropriation becoming final, before which no work was commenced to implement the expropriation purpose, or

- expiration of the term of 10 years from the date of the decision on expropriation becoming final, before which the expropriation purpose failed to have been implemented.

3. Problems with public property management associated with obligation to notify former owners of the possible restitution of properties

The obligation to notify former owners is a consequence of the guideline contained in Art. 136 sec. 1 of (USTAWA 1997), under which the expropriated property cannot be used for any purpose other than the one specified in the expropriation decision. According to this provision, if the expropriated real estate, or part thereof, is intended to be used for a purpose other than the one specified in the expropriation decision, the competent authority notifies the former owner or their heirs of that intent, also informing them about the possibility of restitution of the expropriated property. The content of this provision implies that it is prohibited to use expropriated property for a purpose other than the one specified in the expropriation decision.

The real estate management authority is obliged to find the expropriation documentation, determine the purpose of expropriation and assess whether it was implemented and, if the conditions are met, notify the former owner about the possibility of its restitution. 


\section{S sciendo}

In the case of expropriation decisions issued in the distant past, one of the problems arising in practice is the lack of a specifically defined purpose of expropriation. In the expropriation decisions of the 1950s, the purpose was frequently given in a general and imprecise manner, e.g. "implementation of national economic plans" or "construction of the city". With the purpose of expropriation defined so vaguely, it is difficult to prove the intended purpose of a particular plot of land being a fragment of the expropriated area. Aerial photographs from 1973 are not sufficient evidence in this regard.

In order to assess the issue of redundancy, the purpose of expropriation must be specified. This process is impeded, however, due to the lack of archival documentation. This detailing (clarification) should be carried out based on the analysis of all available documentation collected for the purpose of expropriation proceedings. In such cases, the assessment of the redundancy of a property for the purpose of expropriation must be conducted based on all documents regarding the purpose of expropriation, especially the decisions which determine the location of the investment, decisions approving investment plans, land use plans which are in force at the time of expropriation and documentation to the application for expropriation (Woś 2004). These documents allow to define what specific area with marked boundaries is covered by expropriation and, within this area, what functions are intended for specific expropriated properties by the local land use plan (WYROK 2017).

A period of several decades (e.g. 90 years in the case of expropriation for a military airport in Krakow) results in the documentation being destroyed, incomplete and not allowing for the purpose of expropriation to be specified.

In order to assess the redundancy of the real estate or part thereof for the purpose of expropriation, administrative decisions, or any other documents defining the manner of management of the expropriated property, are irrelevant if they were issued after the date on which the expropriation decision became final, unless they reflect earlier (before the date of expropriation) arrangements.

The consequence of imprecise determination of the purpose of expropriation in expropriation decisions is the inability to assess its implementation. In the case of expropriation for the construction of a housing estate, when assessing the implementation of the purpose, it is necessary to take into account not only the construction of typical residential buildings (blocks of flats), but also other facilities and technical devices that make up the housing estate infrastructure, and which are necessary for the proper functioning of the housing estate and its residents - including commercial buildings, service facilities, accompanying facilities, passageways, parking lots, schools, sports fields and greenery (WYROK 2016).

Another problem with notifying former owners concerns the determination of personal details of expropriated persons, their addresses and their heirs. The circle of heirs must result from the decision on the acquisition of inheritance or from a notarial deed of the inheritance certificate or a notarial deed of acquisition of inheritance (WYROK 2007).

In practice, it is difficult to find the address of the persons who should be notified due to the passage of time (e.g. several dozen years) since the date of expropriation. It may be helpful to apply to the Center for Document Personalization and other institutions. If it is impossible to find the addresses of authorized persons, their notification may be carried out in a public manner, in accordance with Art. 49 of the Act (USTAWA 1960). The problem with determining current addresses of former owners also results from the fact that expropriation decisions from the 1950s did not include any address details of expropriated persons, and sometimes even the identification of expropriated persons was incorrect (KOMISJA 2017).

Implementation of the obligatory notification of former owners also encounters numerous problems resulting from imprecise provisions of the Real Estate Management Act. In the content of Art. 136 of the Act, the wording "intent to use for other purposes", raises interpretation doubts. The provision requires a change by clarifying whether this term means the intent to dispose of the property by, for example, transferring ownership right, or whether it is a different economic purpose or use, or different earmarking in the land use plan. A doubt arises at this point, if the fact that a given real property is covered by a local land use plan means an obligation to analyze its intended purpose in the context of the purpose of expropriation (KOMISJA 2017).

Under the provision of Art. 136 (UsTAWA 1997), it is not allowed to use properties for a purpose other than the one specified in the expropriation decision. On the other hand, Article 139 (UsTAWA 1997) stipulates that the expropriated property is subject to restitution in the condition in which it is on the day it is restituted. In practice, implementation of such regulations raises problems that are difficult to resolve based on applicable regulations. For example, if the property was expropriated for 
the construction of a commercial building and a school was built there - the question is whether this might be a justification for restitution in the light of current regulations.

The results of the conducted analysis lead to the conclusion that it is reasonable to limit the deadline for submitting claims for restitution of expropriated properties. Such cases of limiting the deadline for claims can be found in another legal regulation (Art. 73 of the UsTAWA 1998). In the case that restitution is refused due to an important public interest, a different solution that could be offered would be vesting ownership right to a replacement land or financial compensation.

4. Data on properties subject to obligatory notification of authorized persons about the possibility of restitution in a selected area

The surveying and legal documentation of the Municipality of Krakow regarding properties intended for disposal in years 2015-2017 were analyzed in the aspect of the assessment of property acquisition and, consequently, the obligation to notify former owners and their heirs about the possibility of restitution. Pursuant to the guidelines, real properties that are part of the Krakow City Municipality resources may be either sold or let for perpetual usufruct if it is economically justified and if they were not earmarked for public purposes in the local land use plan or in the decision determining the location of the public purpose. If the property was included into the resource through expropriation, it is, first of all, necessary to determine whether the purpose of the expropriation has been implemented and whether the former owners have a claim for restitution; only then can further steps be taken to notify them of the possibility of restitution.

Table 1

Data regarding properties subject to notification of their possible restitution compared to properties planned for disposal

\begin{tabular}{cccc}
\hline Year & $\begin{array}{c}\text { Number of properties } \\
\text { planned for disposal }\end{array}$ & $\begin{array}{c}\text { Number of properties } \\
\text { disposed of by tender }\end{array}$ & $\begin{array}{c}\text { Number of properties } \\
\text { subject to notification } \\
\text { of their possible } \\
\text { restitution }\end{array}$ \\
\hline 2015 & 52 & 38 & 14 \\
\hline 2016 & 42 & 33 & 9 \\
\hline 2017 & 21 & 15 & 6 \\
\hline Total & 115 & 86 & 29 \\
\hline
\end{tabular}

Source: Source: own study based on data from Department of Treasury of the Municipal Office of the City of Krakow.

According to the research (Tab. 1), in years 2015-2017, the Municipality of Krakow designated 115 properties for disposal by tender. Investment areas suited for independent development are generally disposed of in this procedure. Failure to implement the expropriation purpose in the case of 29 properties resulted in the former owners and their heirs being notified about the possibility of restitution, which consequently eliminated these properties from the disposal process. The number of properties covered by the notice of restitution represented approximately $25 \%$ of all properties planned for disposal. This means that they could not be disposed of or used for investment purposes by the city.

Restitution proceedings for expropriated properties are very complicated and long-lasting (TREMBECKA 2011). The duration of the procedure depends on many different circumstances, including finding archival geodetic documentation, determining all parties to the proceedings, the current legal status of the property and the extent of the areas subject to restitution. The length of restitution procedures means that the final settlement in the form of a decision on restitution or refusal 
thereof usually takes place after a few years. During this time, the properties cannot be developed in a way that prevents their restitution or causes a change in their value.

According to the research, it appears that, from January 1, 1999 until 2018, the President of the City of Krakow decided on the restitution of 543 properties. This number does not include all the plots of the Municipality of Krakow restituted to former owners, because, since October 22, 2007, the President is subject to exclusion from making decisions in cases regarding properties owned by the Municipality.

\section{Conclusions}

The analysis of problems relating to properties which were expropriated a long time ago, in the previous system, leads to the conclusion that amendments to the provisions on restitution are necessary.

One of the problems is the obligation to notify former owners or their heirs about the possibility of restitution of the expropriated property if the expropriated property or part thereof is intended to be used for a purpose other than the one specified in the expropriation decision by the competent authority. The wording "intent to use for other purposes" contained in the content of Art. 136 sec. 2 of (UsTAWA 1997) requires a precise definition, because, in practice, it raises interpretation doubts. It should be clarified whether this concept means the intent to dispose of the property through, for example, transfer of ownership right, or whether it is a different economic purpose, different use or different purpose in the local land use plan.

Due to the fact that the purpose of expropriation was not clearly specified in previous expropriation decisions, and the source documentation is unavailable, the current assessment of its implementation and, as a consequence, notification of authorized persons, is difficult. In addition, finding former owners and their addresses requires tedious months of searching, which do not always bring the desired results.

Due to potential restitution claims, many public areas are "frozen" and there is no possibility of using them for investment purposes, which has a certain influence on the process of public property management.

The performed analysis leads to the conclusion that it is justified to limit the deadline for submitting claims for restitution of expropriated properties, as was the case with other normative regulation. This is dictated by the rational management of public properties while taking into account the principle of social justice. In addition, some consideration should be given to those amendments to the regulations that allow refusal of restitution if the investment differs from the purpose of expropriation, but was built from public funds and is currently used for public purposes.

\section{References}

ACT respecting the expropriation of land (R.S.C., 1985, c. E-21), www.aws-lois.justice.gc.ca, access: 09.04.2018,

BAUGESETZBUCH (BauGB) act of 23 June 1960, Consolidated text of Official Journal of 2017, BGBl. I S. 3634, www.gesetze-im-internet.de, access: 09.04.2018,

Brightman G., 2016, Public Purpose as a Justification for Expropriation of Rural Land Rights in Ethiopia, Journal of African Law, Vol. 60, Issue 2, pp. 190-212,

FAO, 2008, Compulsory Acquisition of Land and Compensation, Rome, http://www.fao.org/3/ai0506e.pdf, access: 09.04.2018,

CODE de l'expropriation pour cause d'utilité publique, 2015, www.legifrance.gouv.fr, access: 09.04.2018,

CONSTitUCión Española, act of 27 December 1978 r. Boletín Oficial del Estado No. 311, 1978, as amended,

CONSTITUTION de la République Française act of 4 October 1958, Journal Officiel de la République Française, No. 234, as amended,

DeCRETO del Presidente della Repubblica, act of 8 June 2001, n. 327, Testo unico delle disposizioni legislative e regolamentari in materia di espropriazione per pubblica utilità, G.U. 16 agosto 2001, n. 189 , s.o. n. 211, ripubblicata il 14 settembre 2001, sul n. 214, s.o. n. 231,

Du Plessis, E. W. J., 2011, Restitution of Expropriated Property Upon the Non-Realisation of the Public Purpose: Harvey V Umhlatuze Municipality Case Note, TSAR, Vol. 3, pp. 580,

FIG Policy Statement, 2010, Compulsory Purchase and Compensation - Recommendations for Good Practice, 
No. 54, https://www.fig.net/resources/publications/figpub/pub54/figpub54.pdf, access: 1.04.2018,

GRUNDGESETZ für die Bundesrepublik Deutschland, act of 23 May 1949, Consolidated text Bundesgesetzblatt Teil III, Gliederungsnummer 100- as amended,

HARRINGTON MP, 2002, "Public use" and the Original Understanding of the So-called "Takings" Clause, Hastings Law Journal, Vol. 53, Issue 6, p. 1245,

JAWORSKI J., PrUSACZYK A., TUŁODZIECKIA., WOlAnin M., 2015, Komentarz do ustawy o gospodarce nieruchomościami (Commentary on the Real Estate Management Act), Warszawa, C.H. Beck, p. 872

KOMISJA GOSPODARKI NIERUCHOMOŚCIAMI ZWIĄZKU MiAST POLSKICH - stanowisko z dnia 30 czerwca 2017 r. "Problematyka zwrotów wywtaszczonych nieruchomości". (Position of 30 June 2017." Issues of returns of expropriated real estate"),

KonstytuCja RzeCZYPOSPOLITEj POlSKIEj z dnia 2 kwietnia 1997 r. (Act of 2 April 1997) Dz.U. Nr 78, poz. 483 z późn.zm. (Journal of Laws, 2004, no. 167, item 1758, as amended),

LuX M., MiKeszovÁ M., 2012, Property Restitution and Private Rental Housing in Transition: The Case of the Czech Republic. Housing Studies, 27(1), pp. 77-96,

Padure L. A.; Tutuianu A., 2015, Ways in Which Some Countries Which Have Totalitarian Regimes Have Solved the Issue of Restitution of the Properties Abusively Confiscated, in 5th International Conference Lumen 2014, Transdisciplinary and Communicative Action (Lumen-TCA 2014), pp. 535-539,

REIMANN B., 1997, The Transition from People's Property to Private Property: Consequences of the Restitution Principle for Urban Development and Urban Renewal in East Berlin's Inner-city Residential Areas. Applied Geography, Volume 17, Issue 4, pp. 301-313,

SumRAdA R., FERLAN M, LiseC A., 2013, Acquisition and Expropriation of Real Property for the Public Benefit in Slovenia, Land Use Policy, Vol. 32, pp. 14-22,

ŚMIAŁOWSKA-Uberman Z., KWARTNIK-PRUC A., 2009, Specific Issues Referring to the Real Estate Expropriation, Geomatics and Environmental Engineering, Vol. 3 No. 1, pp. 39-49,

TREMBECKA A., 2011, Kiedy i na jakich warunkach: zwrot wywłaszczonych nieruchomości (When and Under What Conditions: the Return of Expropriated Property) Geodeta, magazyn geoinformacyjny (Surveyor, Geoinformation Magazine) No. 9, pp. 40 - 45,

TREMBECKA A., 2014, Wybrane problemy dotyczace zwrotu wywlaszczonych nieruchomości, w: Analiza rynku i zarządzanie nieruchomościami (Selected Issues Concerning the Restitution of Expropriated Property, in: Market Analysis and Real Estate Management) Olsztyn, Towarzystwo Naukowe Nieruchomości (Polish Real Estate Scientific Society) Dokument elektroniczny: monografia naukowa (Electronic document: scientific monograph) pp. 149-158.

TREMBECKA A., 2015, Wptyw roszczeń byłych właścicieli nieruchomości na proces gospodarowania mieniem publicznym, w: Rola danych geodezyjnych $\mathrm{w}$ wybranych procesach gospodarki nieruchomościami (The Effect of the Claims Lodged by Former Real Property Owners on Public Property Management Process, in: The Role of Survey Data in Selected Real Esate Management Processes, ) Rzeszów, Wyższa Szkoła Inżynieryjno-Ekonomiczna Rzeszów, Higher School of Engineering and Economics)

TREMBECKA A., 2015, Gospodarka nieruchomościami. Teoria i praktyka (Real Estate Management. Theory and Practice) Kraków, Wydawnictwa AGH (AGH Publishing House), p. 271,

TRIANTIS L., 2018, The Post-socialist Restitution of Property as Dispossession: Social Dynamics and Land Development in Southern Albania, Land Use Policy, Volume 71, pp. 584-592,

UstAWA z dnia 14 czerwca 1960 r. Kodeks postępowania administracyjnego (Act of 14 June 1960, The Code of Administrative Procedure) Dz.U. z 2017 r., poz. 1257 z późn. zm. (Official Journal of 2017, item 1257 , as amended),

UsTAWA z dnia 26 października 1971 r. o uregulowaniu własności gospodarstw rolnych (Act of 26 October 1971 on regulation of agricultural farm property) Dz.U. nr 27, poz. 253 (Journal of Laws No. 27, item. 250, as amended),

UstaWA z dnia 21 sierpnia 1997 r. o gospodarce nieruchomościami, Dz. U z 2018 r., poz. 121 (Act of 21 August 1997 on real estate management, Journal of Laws, 2018, item 121),

UstAWA z dnia 13 października 1998 r. Przepisy wprowadzajace ustawy reformujace administracje publiczna (Act of 13 October 1998, Regulations implementing the Acts reforming public administration), Dz.U. nr 133, poz. 872 z późn. zm. (Journal of Laws no. 133, item 872, as amended),

WALACIK M., 2012, Wybrane zasady i procedury nabywania nieruchomości pod realizacje inwestycji drogowych w Norwegii (Selected Principles and Procedures for the Acquisition of Property for the 
Implementation of Road Projects in Norway) Biuletyn Stowarzyszenia Rzeczoznawców Majątkowych Województwa Wielkopolskiego (Newsletter of the Association of Valuers of the Wielkopolska Region) No. 4,

Walacik M., Richard G., Adamuscin A., 2013, Valuation Systems in Poland, Slovakia and The United Kingdom - Comparative Study, Real Estate Management and valuation, Vol. 21, No. 4, pp. 75-86,

Woś T., 2004, Wywtaszczenie $i$ zwrot wywtaszczonych nieruchomości (Expropriation and Return of Expropriated Real Estate) Lexis Nexis Warszawa, p. 210,

WYROK Naczelnego Sądu Administracyjnego z dnia z 27 kwietnia 2007 r., (Judgment of the Supreme Administrative Court of 27 April, 2007), sygn. akt I OSK 844/06, publ. CBOSA, http./ / orzeczenia.nsa.gov.pl, access: 02.02.2018,

WYroK Wojewódzkiego Sądu Administracyjnego w Lublinie z dnia 19 lipca 2016 r. (Judgment of the Provincial Administrative Court in Lublin of 19 July, 2016) sygn. akt II SA/Lu 204/16.publ. CBOSA, http.//orzeczenia.nsa.gov.pl access: 09.02.2018,

WYROK Naczelnego Sądu Administracyjnego w Warszawie z dnia 14 czerwca 2017 r. sygn. akt I OSK 2625/16 publ. CBOSA, (Judgment of the Supreme Administrative Court in Warsaw of June 14, 2017), http./ / orzeczenia.nsa.gov.pl access: 09.02.2018,

ŹRóBEK R., 2006, Teoria i praktyka wywłaszczania nieruchomości w Polsce i Niemczech (Theory and Practice of Property Expropriation in Poland and Germany) Acta Scientiarum Polonorum, Administratio Locorum 5/1/2, pp. 5-16,

ŹRÓBEK S, ŹRÓBEK R., 2007, Nabywanie nieruchomości na potrzeby rozwoju miast z zastosowaniem procedury wywtaszczeniowej (Acquisition of Real Estate for the Needs of Urban Development with the Expropriation Procedure) Problemy Rozwoju Miast No. 4/4, pp. 67-74,

ŹRÓBEK R, ŹRóBEK S, 2008, Expropriation as an Exceptional Tool of Acquisition of Land for Public Purposes, Geomatics and Environmental Engineering, Volume 2, Number 1, pp. 85-94,

ŹRÓBEK S., WALACIK M., 2008, Analiza porównawcza wybranych zagadnień wywłaszczania w Polsce i za granica (Comparative Analysis of Selected Issues of Real Estate Expropriation in Poland and Abroad), Przegląd Geodezyjny No. 12, pp. 4-9. 